\title{
Eksplorasi Etnomatematika Pada Motif Kain Buna Masyarakat Insana Tengah
}

\author{
Aurelya Y. Haki Natun ${ }^{*}$, Oktovianus Mamoh², Stanislaus Amsikan ${ }^{3}$ \\ $1^{*}, 2$ \& 3 Universitas Timor \\ aurelyanatun@gmail.com \\ *penulis korespondensi
}

\begin{tabular}{|c|c|}
\hline Informasi Artikel & Abstrak \\
\hline $\begin{array}{l}\text { Revisi: } \\
19 \text { Mei } 2021\end{array}$ & $\begin{array}{l}\text { Penelitian ini merupakan penelitian kualitatif dengan pendekatan etnografi yang } \\
\text { bertujuan untuk mengeksplorasi konsep-konsep matematika yang ada pada kain } \\
\text { tenun motif buna. Penelitian ini dilaksanakan di Desa Letmafo, Kecamatan } \\
\text { Insana Tengah, Kabupaten Timor Tengah Utara. Subjek penelitian adalah dua }\end{array}$ \\
\hline Diterima: & orang pengrajin tenun dan objek penelitian adalah kain tenun motif buna. \\
\hline 25 Juli 2021 & $\begin{array}{l}\text { Instrumen penelitian berupa human instrument, pedoman observasi dan pedoman } \\
\text { wawancara. Teknik pengumpulan data yang digunakan dalam penelitian ini }\end{array}$ \\
\hline Diterbitkan: & adalah observasi, wawancara dan dokumentasi. Analisis data dilakukan melalui \\
\hline 31 Agustus 2021 & $\begin{array}{l}\text { tiga tahap yaitu reduksi data, display data dan penarikan kesimpulan. Hasil } \\
\text { penelitian yang diperoleh adalah sebagai berikut: ditemukan konsep-konsep }\end{array}$ \\
\hline Kata Kunci & matematika seperti konsep geometri (bangun datar) yaitu: Belah ketupat, \\
\hline Eksplorasi & Segitiga, Persegi, Titik, Garis berpotongan, Pencerminan atau Refleksi, dan \\
\hline Etnomatematika & Garis sejajar. Hal ini menunjukkan bahwa matematika tumbuh dan berkembang \\
\hline Motif buna & dalam aktivitas masyarakat tertentu yang disebut dengan istilah etnomatematika. \\
\hline
\end{tabular}

\begin{abstract}
This research is a qualitative research with an ethnography approach that aims to eksplore the existing mathematical concepts in the women cloth on buna motifs. The study was conducted in Letmafo village, Central Insana subdistrict, Nort Central Timor district. Research subject is two weaving craftsmen and research object is buna motifs. The research instruments are human instrument, observasi guideline and interview guide. Data collection tecniques used in this study are obsevation, interview and dokumentation. Data analysis is done throught three stage: data reduction, data display and drawing conclusions. The result obtained are as follows: geometri concept (two dimentional figure) that is: rhombus, triangle, square, point, mirror lines, reflection, and paralel lines. This shows that mathematics grows and develops in activity society called the term etnomatematics.
\end{abstract}

\section{Pendahuluan}

Matematika tanpa disadari sudah menjadi bagian dalam kehidupan manusia sehari-hari. Hal ini terlihat dari berbagai kelompok budaya yang berbeda telah menggunakan matematika yang berbeda satu dengan yang lainnya (Walle, 2006). Gagasan untuk memanfaatkan unsur sosial budaya ke dalam matematika telah diprakarsai sejak tahun 1977 oleh seorang matematikawan Brazil, Ubiratan D'Ambrosio. Istilah yang menghubungkan matematika dengan budaya masyarakat disebut etnomatematika. Etnomatematika mencakup kehidupan budaya masyarakat yang meliputi pertanian, seni ukir/pahat, tenun, mitos, simbol, bahasa, dan perilaku (Funan, 2019).

Tenun merupakan salah satu seni budaya kain tradisional yang di produksi di berbagai wilayah di Indonesia termasuk pulau Timor, yang proses pembuatannya masih menggunakan alat-alat tradisional dan umumnya dilakukan oleh kaum perempuan. Keunikan motif tenunan dari setiap wilayah berbeda beda. Jenis-jenis motif tenunan di Kabupaten Timor Tengah Utara juga berbeda-beda antar setiap suku. Masyarakat Insana Tengah sudah sejak lama membuat, memakai dan memperdagangkan kain tenun ikat. Tenunan masyarakat Insana Tengah terdiri atas beragam corak 
dan motif yang tentunya memiliki keunikan dan kekhasan sendiri-sendiri, motif buna yang dituangkan merupakan hasil-cipta rasa dan karsa penenun berdasarkan latar belakang sejarah dan filosofi hidup masyarakat Insana Tengah. Kain tenun di masyarakat Insana Tengah memiliki banyak arti dan fungsi secara budaya sebagai pakaian yang dipakai dalam tari-tarian pada acara atau ritus-ritus adat seperti acara kematian, pernikahan, penjemputan tamu. Selain itu tenunan ini juga biasanya dipakai sebagai pakaian sehari-hari baik pria maupun wanita. Busana dari tenunan ini berupa selimut (bete) dan sarung (tais), yang mana bete hasil tenunan yang digunakan pria, sedangkan tais digunakan wanita. Tujuan dari penelitian ini adalah untuk mengeksplorasi konsep matematika yang terdapat dalam motif kain buna masyarakat Insana Tengah.

Berbagai penelitian untuk mengeksplorasi etnomatematika pada budaya di Kabupaten Timor Tengah Utara ini telah banyak dilakukan seperti penelitian Amsikan \& Nahak (2017) terhadap struktur arsitektur ume kbubu desa Kaenbaun, Deda dan Disnawati 92017) mengungkap hubungan motif kain tenun masyarakat suku Dawan-Timor, Funan \& Mamoh (2019) mengeksplorasi etnomatematika pada uem le'u Insana dan (Son 2017) mengeksplorasi konsep matematika pada permainan kelereng masyarakat Suku Dawan. Budaya adalah segala hasil pikiran, perasaan, kemauan dan karya manusia secara individual atau kelompok untuk meningkatkan hidup dan kehidupan manusia atau secara singkat adalah cara hidup yang telah dikembangkan oleh masyarakat. Dengan demikian budaya bisa dalam bentuk benda-benda kongkrit dan bisa juga bersifat abstrak. Benda-benda kongkrit misalnya, bangunan rumah, barang-barang seni, tindakan-tindakan seni seperti cara menerima tamu, cara duduk, cara berpakaian, dan sebagainya. Sedangkan contoh yamg abstrak ialah cara berfikir ilmiah, kemampuan menciptakan sesuatu, imajinasi, cita-cita, kemauan yang kuat untuk mencapai sesuatu, keimanan, dan sebagainya (Indriaini, 2016). Hal ini dapat dikatakan bahwa budaya merupakan sesuatu yang tidak bisa dihindari dalam kehidupan sehari-hari, karena budaya merupakan kesatuan utuh dan menyeluruh yang berlaku dalam suatu komunitas, sehingga memungkinkan adanya konsep-konsep matematika yang tertanam dalam praktik-praktik budaya dan mengakui bahwa semua orang mengembangkan cara khusus dalam melakukan aktivitas matematika disebut etnomatematika.

\section{Kebudayaan}

Menurut Daoed Joesoef (Putri, 2017) Kebudayaan diartikan sebagai semua hal yang terkait dengan budaya. Dalam konteks ini tinjauan budaya dilihat dari tiga aspek, yaitu pertama, budaya yang universal yaitu berkaitan nilai-nilai yang universal yang berlaku dimana saja yang berkembang sejalan dengan perkembangan kehidupan masyarakat dan ilmu pengetahuan atau teknologi. Kedua, budaya nasional, yaitu nilai-nilai yang berlaku dalam masyarakat Indonesia secara nasional. Ketiga, budaya lokal yang eksis dalam kehidupan masyarakat setempat, sementara menurut Edwar B. Taylor (Septi 2017) kebudayaan adalah totalitas yang kompleks yang mencangkup pengetahuan, kepercayaan, seni, hukum, moral, adat dan kemampuan-kemampuan serta kebiasaan-kebiasaan yang diperoleh orang sebagai anggota masyarakat, kebudayaan itu akan terus berjalan dengan perkembangan zaman, percepatan perkembangan ilmu dan teknologi, serta perkembangan kepandaian manusia. Dari beberapa definisi di atas, dapat disimpulkan bahwa kebudayaan merupakan sesuatu yang akan mempengaruhi tingkat pengetahuan meliputi sistem ide atau gagasan yang terdapat dalam pikiran manusia, sehingga dalam kehidupan sehari-hari, kehidupan itu bersifat abstrak. Sedangkan perwujudan kebudayaan adalah benda-benda yang diciptakan oleh manusia sebagai makhluk yang berbudaya, berupa perilaku dan benda-benda yang bersifat nyata, misalnya pola-pola perilaku, bahasa, peralatan hidup, organisasi seni, dan lain-lain, semuanya itu ditunjuk untuk membantu manusia dalam melangsungkan kehidupan bermasyarakat. Perubahan itu bisa bersumber dari ketiga hal tersebut:

1) Organisasi, yaitu sesuatu yang baru atau penemuan-penemuan yang baru.

2) Difusi, ialah pembentukan kebudayaan baru akibat masuknya elemen-elemen budaya yang baru ke dalam budaya yang lama.

3) Reinterpesi, ialah perubahan kebudayaan akibat terjadinya modifikasi elemen-elemen kebudayaan yang telah ada agar sesuai dengan keadaan zaman. 


\section{MATH-EDU: Jurnal Ilmu Pendidikan Matematika}

https://doi.org/10.32938/jipm.6.2.2021.31-41

Natun, A. Y. H., dkk.

\section{Unsur-unsur kebudayaan}

Unsur-unsur kebudayaan dibagi menjadi tujuh unsur menurut Koentjaraningrat (Fudiyartanto 2012), yaitu:

1) Bahasa, merupakan wujud ilmu komunikasi yang mencakup bahasa daerah, pantun syair, novelnovel dan lain sebagainya.

2) Sistem pengetahuan, meliputi science (ilmu-ilmu eksak) dan humanities (sastra, filsafat, sejarah, dan sebagainya).

3) Organisasi sosial, meliputi upacara-upacara (kelahiran, pernikahan, dan kematian).

4) Sistem peralatan hidup dan teknologi, meliputi pakaian, makanan, minuman, alat-alat upacara, dan kemajuan teknologi lainnya.

5) Sistem mata pencaharian hidup, merupakan segala usaha manusia untuk mendapatkan barang dan jasa yang dibutuhkan. Sistem ekonomi ini meliputi: berburu dan mengumpulkan makanan, bercocok tanam, peternakan, perikanan, dan upacara perdagangan.

6) Sistem religi, meliputi sistem keyakinan, dan gagasan tentang Tuhan, dewa-dewa, roh neraka, surga, maupun berupa upacara adat maupun benda-benda suci dan benda-benda religius (candi dan patung nenek moyang) dan lainnya.

7) Kesenian, berupa seni rupa (lukisan), seni pertunjukkan (tari, musik), seni teater (wayang), seni arsitektur (rumah, bangunan, perahu, candi, dan lain sebagainya), berupa benda-benda indah, atau kerajinan.

\section{Etnomatematika}

Istilah etnomatematika diperkenalkan pertama kali oleh D'Ambrosio, seorang matematikawan Brasil pada tahun 1977. Menurut D'Ambrosio (1985) etnomatematika merupakan studi tentang matematika yang memperhitungkan pertimbangan budaya dimana matematika muncul dengan memahami penalaran dan sistem matematika yang mereka gunakan. Etnomatematika sering juga disebut dengan istilah etnomathematic. Istilah etno diartikan sebagai sesuatu yang sangat luas yang mengacu pada konteks sosial budaya, termasuk bahasa, jargon, kode perilaku, mitos, dan simbol. Kata dasar mathema cenderung berarti menjelaskan, mengetahui, memahami dan melakukan kegiatan seperti pengkodean, mengukur, mengklasifikasi, menyimpulkan, dan pemodelan. Akhiran "tics" berasal dari techne, dan bermakna teknik. Zang dan Zang (2010) mendefinisikan etnomatematika sebagai penelitian tentang hubungan antara matematika dan latar belakang budaya sosial. Zang dan Zang (2010) juga menyebutkan bahwa etnomatematika merupakan penelitian bagaimana menunjukkan matematika diproduksi, ditransfer, menyebar, dan khusus dalam sistem budaya yang beragam.

Menurut Puspadewi (2014), etnomatematika merupakan matematika yang muncul sebagai akibat pengaruh kegiatan yang ada di lingkungan yang dipengaruhi oleh budaya. Hal ini menekankan bahwa etnomatematika merupakan matematika yang berkembang dan tumbuh sesuai dengan kehidupan masyarakat di dalam budaya tertentu. Menurut Kofi dan Mamoh, (2020) etnomatematika dapat dipandang sebagai suatu pendekatan pembelajaran yang dapat membantu siswa menemukan konsep-konsep matematika secara realistis melalui budaya, juga dapat mendorong siswa mencintai serta membudayakan budaya yang telah ada.

Etnomatematika menurut NASGEM, Amerika Utara Study Group Of Ethnomathematics (Arisetyawan et al.,2014) didefinisikan secara luas bahwa studi etnomatematika tidak terbatas pada skala kelompok kecil, tapi awalan "etno" dapat merujuk kepada kelompok apapun seperti bangsa, serikat buruh, agama, tradisi, dan sebagainya, termasuk penggunaan simbol-simbol matematika, tata ruang, metode perhitungan, pengukuran dalam ruang dan waktu, cara-cara tertentu penalaran dan kegiatan manusia lainnya yang dapat diterjemahkan ke dalam representasi matematis formal.

Berdasarkan definisi-definisi di atas etnomatematika dapat diartikan sebagai matematika yang dipraktikkan oleh kelompok budaya, seperti masyarakat perkotaan dan pedesaan, kelompok buruh, anak-anak dari kelompok usia tertentu, masyarakat adat, dan lainnya. Adanya etnomatematika adalah untuk mengakui bahwa cara-cara berbeda dalam melakukan matematika dengan mempertimbangkan 


\section{MATH-EDU: Jurnal Ilmu Pendidikan Matematika}

https://doi.org/10.32938/jipm.6.2.2021.31-41

Natun, A. Y. H., dkk.

pengetahuan matematika akademik yang dikembangkan oleh berbagai sektor masyarakat serta dengan mempertimbangkan modus yang berbeda di mana budaya yang berbeda merundingkan praktik matematika mereka cara mengelompokkan, berhitung, mengukur, merancang bangunan atau alat, bermain, dan lainnya.

\section{Kain Tenun Motif Buna}

Tenun merupakan salah satu seni budaya kain tradisional Indonesia yang diproduksi di berbagai wilayah di seluruh Inonesia (Jawa, Sumatra, Aceh, Sulawesi, NTB, Bali, dan termasuk NTT). Tenun memiliki makna, nilai sejarah dan teknik yang tinggi baik dari segi warna, motif, jenis bahan dan benang yang digunakan di setiap daerah memiliki ciri khas tersendiri, termasuk tenun yang dihasilkan oleh masyarakat Insana Tengah di desa Letmafo kabupaten Timor Tengah Utara.
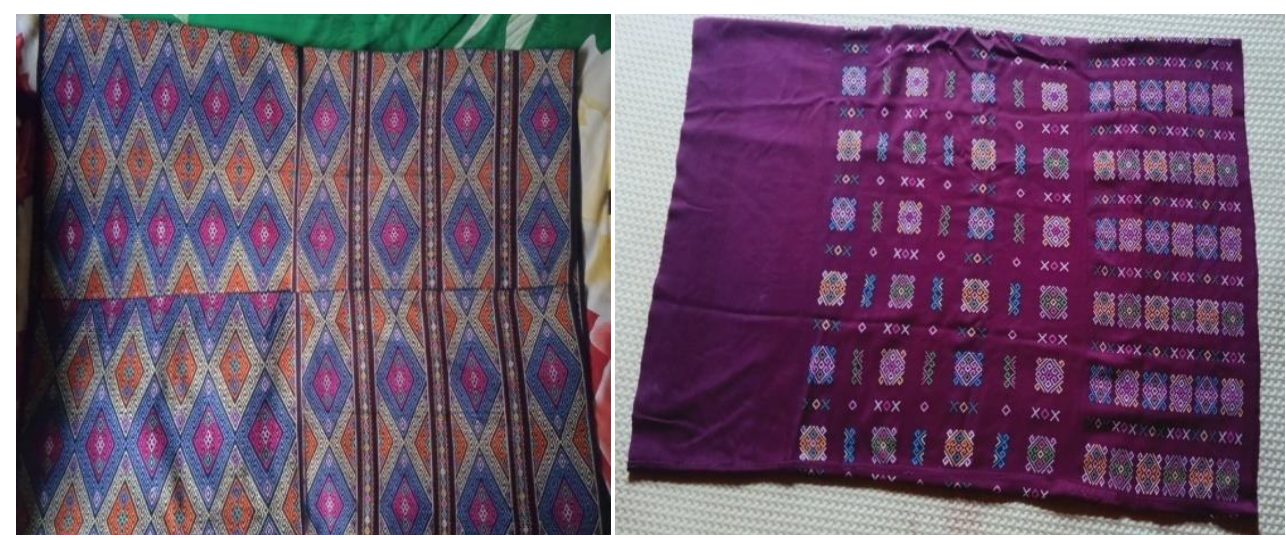

Gambar 1 kain tenun buna manoeb dan kain tenun buna mabata

Kain tenun motif buna merupakan salah satu jenis kain tradisional yang ada di Insana Tengah yang menjadi kekhasan dan menjadi warisan budaya masyarakat Insana Tengah yang mendiami Kabupaten Timor Tengah Utara Provinsi Nusa Tenggara Timur. Dalam penelitian ini, peneliti ingin mengkaji lebih dalam tentang konsep matematika dengan motif kain buna masyarakat Insana Tengah di Kabupaten Timor Tengah Utara. Menurut Deda \& Disnawati (2017) di dalam budaya teknik menenun, bahan yang digunakan adalah benang kapas, yang banyak ditanam dan terdapat dalam daerah-daerah kering. Namun seiring berjalannya waktu, pengrajin tenun menggunakan benangbenang sintesis buatan pabrik karena benang kapas sudah punah dan pada umumnya dikerjakan para wanita menggunakan alat tenun tradisional.

\section{Metode}

Jenis penelitian yang digunakan adalah penelitian kualitatif dengan pendekatan etnografi. Penelitian kualitatif merupakan penelitian yang naturalistik, dalam penelitian naturalistik peneliti sendiri yang menjadi instrumen utama yang terjun langsung ke lapangan untuk mendapatkan sebuah data melalui observasi dan wawancara sebagaimana adanya tanpa dimanipulasi Nasution (2003). Teknik pengumpulan data dalam penelitian ini adalah observasi, wawancara dan dokumentasi. Prosedur penelitian merupakan uraian mengenai langkah-langkah yang akan dilakukan sebagai pedoman untuk melaksanakan penelitian. Indrawati (Munawwaroh 2016) membagi tahapan penelitian kualitatif dalam tiga tahap yakni: tahap persiapan, tahap pelaksanaan, dan tahap pengolahan data.

Penelitian ini menggunakan teknik analisis data deskriptif kualitatif. Deskriptif kualitatif adalah pengolahan data dalam bentuk kata-kata bukan berupa data statistik. Analisis data kualitatif dalam penelitian ini adalah analisis data hasil dari wawancara yang dilakukan pada saat awal penelitian sampai akhir kegiatan penelitian. Adapun tahap-tahap analisis data dalam penelitian ini adalah sebagai berikut: 
1. Reduksi data

Bertujuan mempermudah pemahaman-pemahaman terhadap data yang telah dikumpulkan sehingga dapat dirangkum, dan diklasifikasikan sesuai masalah dan aspek permasalahan yang diteliti.

2. Penyajian data

Hasil reduksi data observasi dan wawancara akan diuraikan dalam bentuk deskriptif. Pemaparan data deskriptif akan dilengkapi dengan gambar yang menerangkan uraian dimaksud.

3. Penarikan kesimpulan

Penarikan kesimpulan didasarkan pada hasil penelitian yang memuat keterkaitan antara matematika dengan pola dan bentuk motif kain buna.

\section{Hasil dan Pembahasan}

\section{a. Kain buna manoeb bagian tengah (aof)}

Manoeb berasal dari bahasa dawan yang artinya sambung menyambung. Kain buna dibawah ini motifnya sambung menyambung antara motif yang satu dengan yang lainnya. Pada bagian tengah (aof) ini terdapat beberapa motif yang berbentuk simetris serta simbol dari matematika. Tiap kain buna yang ditenun mempunyai makna atas motif yang dibuat. Pola- pola yang disusun untuk menghasilkan motif, tentunya lewat motif itu memberi makna. Makna yang terkandung dalam motif buna yakni persatuan masyarakat, dalam kehidupan setiap hari ada keterkaitan antara manusia yang satu dengan yang lain hal ini dapat di lihat pada mak'aif yang saling kait mengait. Di dalam belah ketupat ada belah ketupat kecil, belah ketupat kecil itu melambangkan para penari baik penari pria maupun wanita (abilut, abso'ot) dan meo/panglima bertugas untuk menjaga raja dalam sebuah upacara adat.

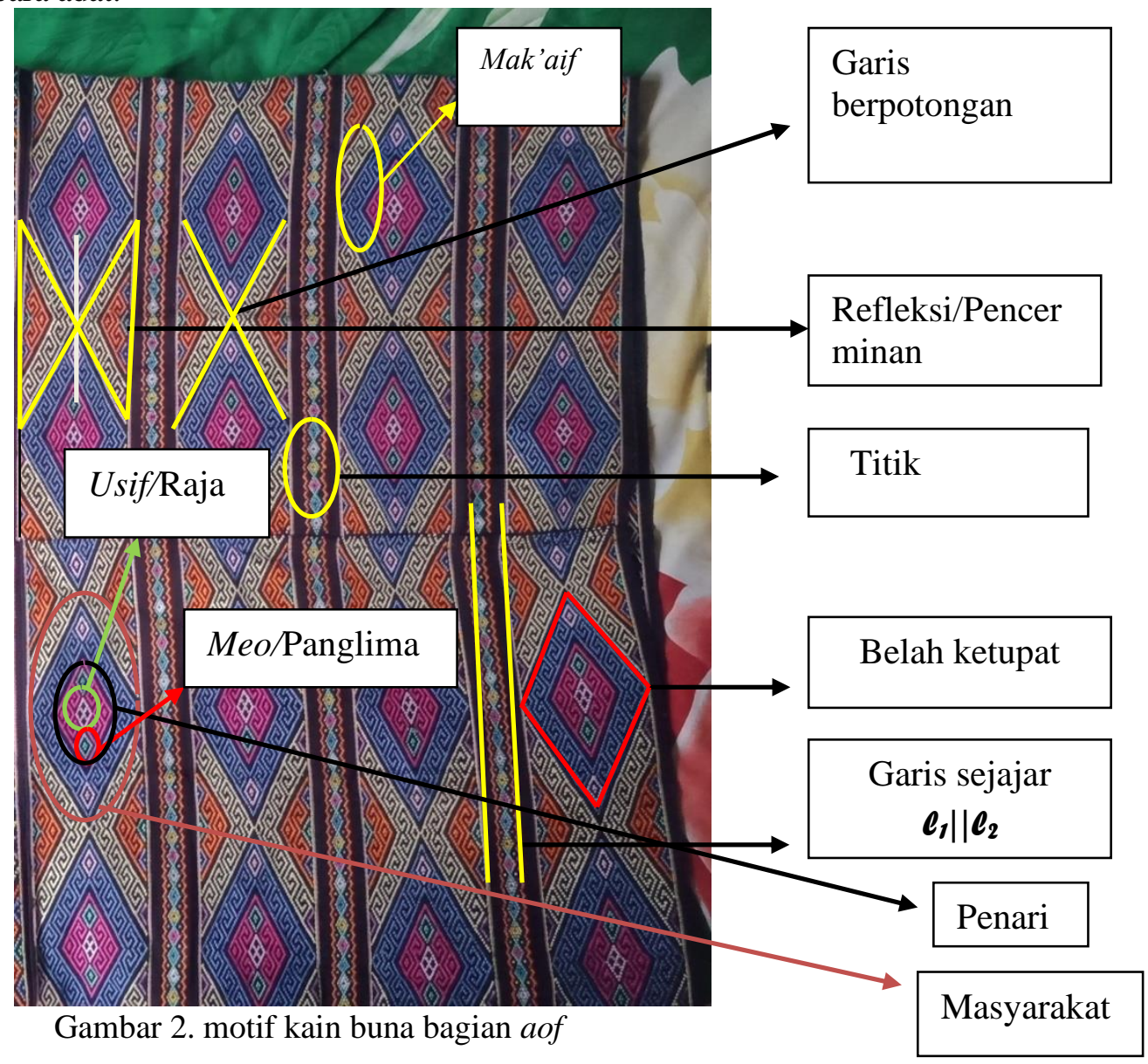




\section{b. Kain buna manoeb bagian bawah (lukaf)}

Kain buna dibawah ini motifnya sambung menyambung antara motif yang satu dengan yang lainnya. Pada bagian bawah (lukaf) makna dari simbol kain tenun buna sama dengan kain buna manoeb bagian tengah (aof).

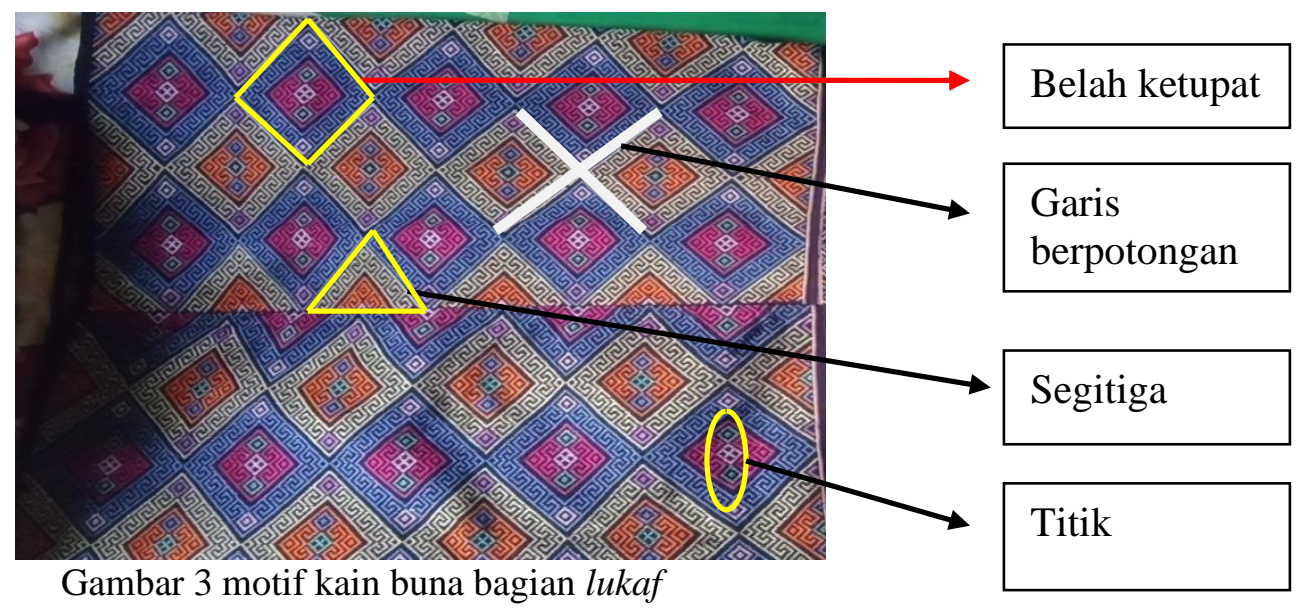

Berdasarkan gambar 2 dan 3, terlihat bahwa ada beberapa konsep matematika yang termuat dalam motif kain buna manoeb bagian aof dan lukaf yang dianalisis sebagai berikut:

1. Pencerminan/refleksi

Pencerminan/refleksi merupakan transformasi yang memindahkan setiap titik pada suatu bidang dengan menggunakan sifat bayangan cermin dari titik-titik yang dipindahkan. sifat-sifat dari pencerminan/refleksi yaitu:

(a) bangun (objek) yang dicerminkan (refleksi) tidak mengalami perubahan bentuk dan ukuran.

(b) Jarak bangun (objek) dari cermin (cermin datar) adalah sama dengan jarak bayangan cermin tersebut.

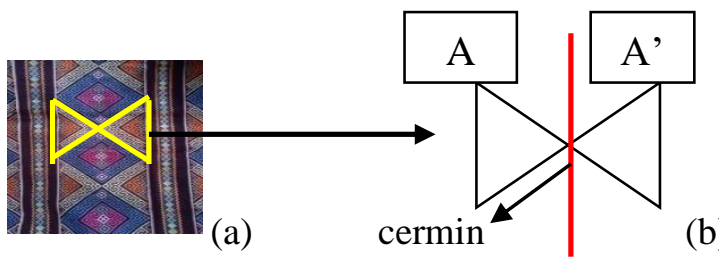

Gambar 4 (a) motif kain buna (b) konsep pencerminan/Refleksi

2. Titik

Titik tidak dapat didefinisikan, tidak berbentuk dan tidak mempunyai ukuran. Titik merupakan suatu ide yang abstrak. Sebuah titik dilukiskan dengan tanda noktah, kemudian dibubuhi dengan dengan nama titik itu. Nama sebuah titik biasanya menggunakan huruf kapital seperti A, B, C.

- $\mathrm{A}=$ Titik A

- $\mathrm{B}=$ Ttitik B

- $\mathrm{C}=$ Ttitik C

Sifat-sifat dari titik yaitu: tidak memiliki bentuk. 


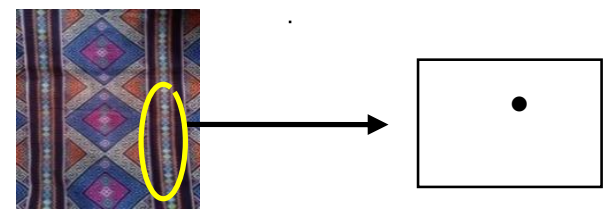

(a)

(b)

Gambar 5 (a) motif kain buna (b) titik

3. Belah Ketupat

Belah ketupat merupakan salah satu bangun datar yang tersusun atas empat sisi yang sama panjang dan sudut yang berhadapan sama besar.

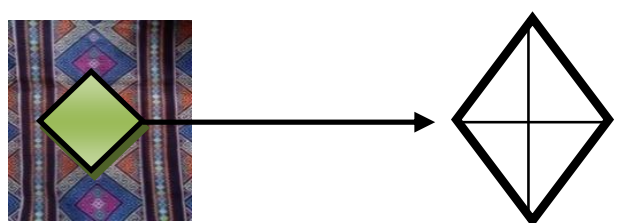

(a) (b)

Gambar 6 (a) motif kain buna (b) konsep belah ketupat

Dari gambar 6 (a) dapat dimodelkan secara geometri berbentuk belah ketupat. Dari gambar tersebut, dapat diketahui bahwa pemodelan tersebut berbentuk bangun datar yang memiliki empat sisi. Berdasarkan hal tersebut, peneliti selanjutnya menganalisis konsep bangun datar belah ketupat pada motif buna tersebut (gambar 6 (b) ). Berdasarkan analisis pada gambar 6 (b), maka dapat disimpulkan bahwa terdapat konsep belah ketupat. Adapun sifat-sifat belah ketupat yang ditemukan pada pemodelan motif kain buna yaitu sebagai berikut:

a. Memiliki empat buah sisi yang sama panjang

b. Sudut-sudut yang berhadapan sama besar

c. Memiliki dua buah diagonal yang saling berpotongan tegak lurus

d. Mempunyai dua simetri putar dan dua simetri lipat.

4. Garis Berpotongan

Garis berpotongan adalah kedudukan dua garis yang mempunyai titik potong karena kedua garis saling bertemu. Secara geometri garis-garis yang berpotongan terjadi karena mempunyai kemiringan yang berbeda dan panjang antar garis memungkinkan untuk saling bertemu.

Sifat-sifat dari garis berpotongan yaitu:

a. Kedua garis yang berpotongan terletak di bidang datar

b. Kedua garis memiliki titik temu

c. Jarak antara dua garis tidak konstan

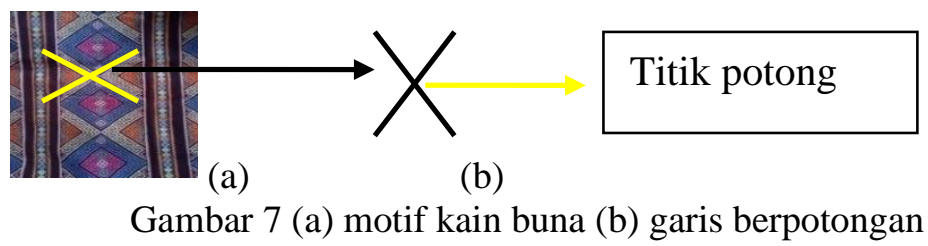

5. Garis Sejajar

Garis sejajar adalah suatu kedudukan dua garis pada bidang datar yang tidak mempunyai titik potong walaupun kedua garis diperpanjang. 
Sifat-sifat dari garis sejajar yaitu:

a. Dua garis yang saling sejajar tidak memiliki titik potong

b. Dua garis yang sejajar akan berada pada bidang yang sama.

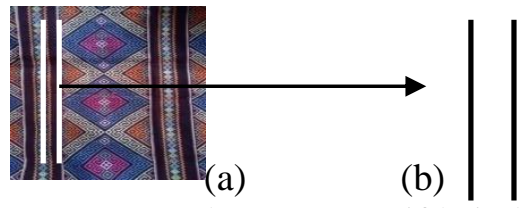

Gambar 8 (a) motif kain buna (b) garis sejajar

6. Segitiga

Segitiga merupakan bangun datar yang memiliki tiga sisi dan tiga sudut.

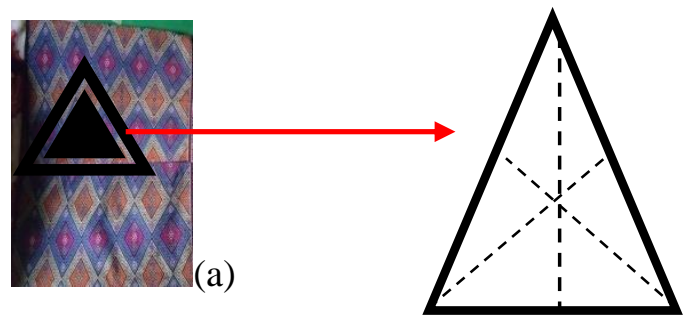

Gambar 9 (a) motif kain buna (b) konsep segitiga sama sisi)

Berdasarkan gambar 9 (a), dapat diketahui bahwa pemodelan tersebut berbentuk bangun datar yang memiliki tiga sisi. Berdasarkan hal tersebut, peneliti selanjutnya menganalisis konsep bangun datar yaitu segitiga sama sisi pada motif buna bagian bawah (lukaf) tersebut ( gambar 9 (b) ). Berdasarkan gambar 9 (b), maka dapat disimpulkan bahwa terdapat konsep segitiga sama kaki pada motif kain buna tersebut. Adapun sifat-sifat segitiga sama sisi yang dapat ditemukan pada motf buna sesuai dengan ganbar 9 (b) yaitu sebagai berikut:

a. Panjang sisinya sama

b. Memiliki 3 sudut yang sama besar yaitu $60^{\circ}$

c. Memiliki 3 simetri lipat dan 3 simetri putar artinya, apabila segitiga sama sisi tersebut dilipat dan di putar bangun tersebut akan sama.

\section{Kain buna mabata bagian bawah (lukaf)}

Pada bagian ini motifnya hampir sama dengan bagian tengah (aof) hanya saja pada bagian lukaf ini selain ada pola utama ada juga pola apit, dengan ukuran panjang dan lebarnya adalah 66 $\mathrm{cm}$ dan $46 \mathrm{~cm}$. Ukurannya sama dengan kain buna manoeb. Akan tetapi untuk bentuk motif manoeb dan mabata tidak sama, mabata motifnya berjarak. Biasanya jarak antara pola utama dan pola apit dihitung dengan lilitan-lilitan benang 6 urat horizontal (monaf) sebanyak 20 kali.

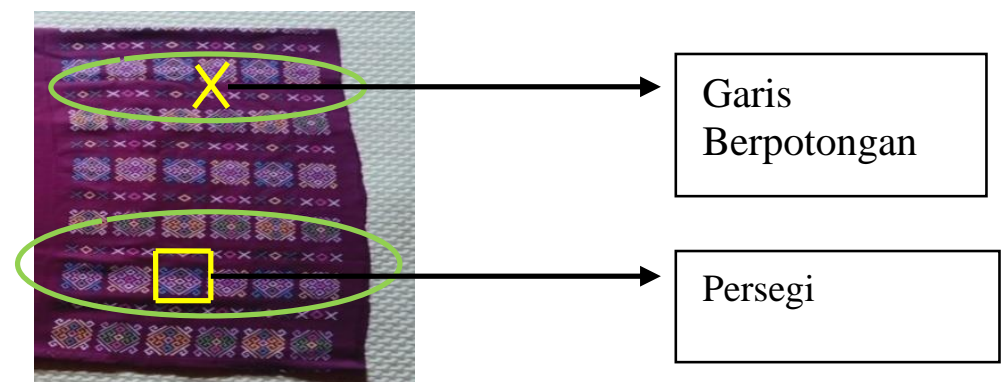

Gambar 10 kain buna mabata bagian lukaf 


\section{d. Kain buna mabata bagian tengah (aof)}

Mabata berasal dari bahasa dawan yang artinya berjarak. Kain tenun dibawah ini motifnya berjarak, antara motif yang satu dengan motif yang lainnya. Makna budaya yang terkandung dalam motif ini sama dengan motif kain buna manoeb yakni persatuan masyarakat.

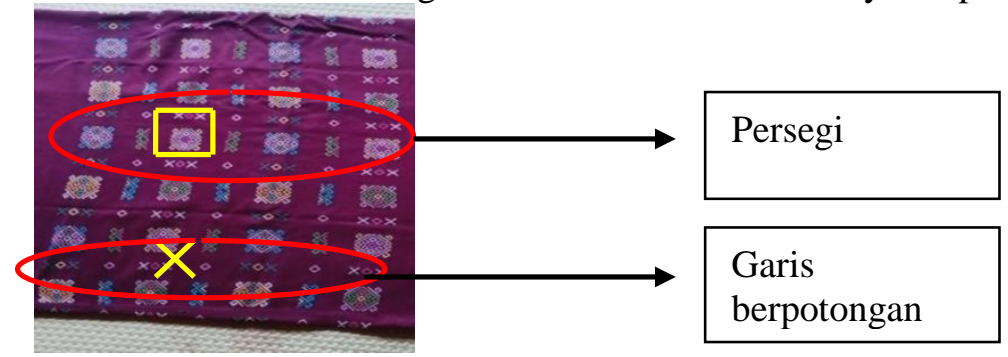

Gambar 11 Kain buna mabata bagian aof

Berdasarkan gambar 10 dan 11, terlihat bahwa ada beberapa konsep matematika yang termuat dalam kain buna mabata bagian lukaf dan aof yang dianalisis sebagai berikut:

1. Garis berpotongan

Garis berpotongan adalah kedudukan dua garis yang mempunyai titik potong karena kedua garis saling bertemu. Secara geometri garis-garis yang berpotongan terjadi karena mempunyai kemiringan yang berbeda dan panjang antar garis memungkinkan untuk saling bertemu.

Sifat-sifat dari garis berpotongan yaitu:

a. Kedua garis yang berpotongan terletak di bidang datar

b. Kedua garis memiliki titik temu

c. Jarak antara dua garis tidak konstan
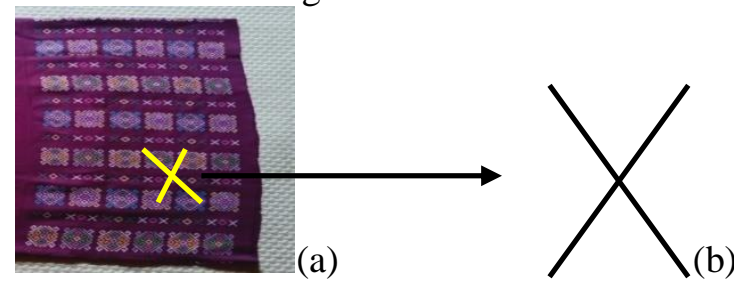

Gambar 12 (a) motif kain buna mabata (b) garis berpotongan

2. Persegi

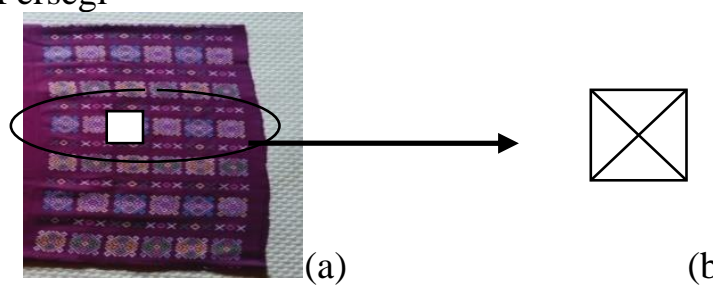

Gambar 13 (a) motif kain buna (b) konsep persegi

Berdasarkan gambar 13 (a) dapat disimpulkan bahwa terdapat konsep persegi pada motif kain buna yang kemudian pemodelannya seperti pada 13 (b). Berdasarkan gambar 13 (b), dapat diketahui bahwa pemodelan tersebut berbentuk bangun datar yang memiliki empat sisi. Berdasarkan hal tersebut, selanjutnya peneliti menganalisis konsep bangun datar persegi pada motif kain buna. Berdasarkan analisis pada gambar 13(b) maka dapat disimpulkan terdapat konsep persegi pada motif kain buna tersebut. Adapun sifat-sifat persegi yang dapat ditemukan pada pemodelan motif buna sesuai pada gambar 13 (b) yaitu sebagai berikut:

a. Mempunyai empat sisi yang sama panjang

b. Mempunyai empat sudut yang sama besar $\left(90^{\circ}\right)$ 


\section{MATH-EDU: Jurnal Ilmu Pendidikan Matematika}

https://doi.org/10.32938/jipm.6.2.2021.31-41

Natun, A. Y. H., dkk.

c. Mempunyai empat simetri putar

Simpulan

d. Mempunyai empat simetri lipat

Makna filosofi yang terkandung dalam motif kain buna yakni persatuan masyarakat.

Berdasarkan uraian pada bagian hasil dan pembahasan, maka dapat disimpulkan bahwa konsep dan prinsip matematika yang ditemukan dalam motif kain tenun buna antara lain:

1. Konsep Matematika

Konsep matematika terdiri-dari bangun datar berupa persegi, belah ketupat, dan segitiga.

2. Prinsip-prinsip matematika yang terdapat pada motif kain tenun buna berupa garis Saran berpotongan, dan refleksi/pencerminan yang ditemukan pada motif kain buna.

Berdasarkan hasil penelitian ini, mengingat pentingnya eksplorasi pemahaman tentang nilai-nilai budaya dalam sudut pandang matematika, maka dapat dikemukakan beberapa saran sebagai berikut:

1. Bagi Masyarakat Insana Tengah

Sebagai landasan dasar bagi masyarakat setempat untuk menambah wawasan tentang nilai matematika yang terkandung dalam aktivitas masyarakat.

2. Bagi Pembaca

Sebagai salah satu sumber referensi dan informasi supaya mengetahui lebih dalam tentang keterkaitan konsep matematika dengan budaya.

\section{Referensi}

Amsikan, S., \& Nahak, S. (2017). Hubungan Konsep Ruang Ume Kbubu Desa Kaenbaun Kabupaten Timor Tengah Utara Dengan Konsep Geometri. Prosiding Konferensi Nasional Penelitian Matematika dan Pembelajarannya II (KNPMP II) Universitas Muhammadiyah Surakarta, 18 Maret 2017. Hal. 168-175.

Arisetyawan, A., Suryadi, D., Herman, T., Rahmat, C., \& No, J. D. S. (2014). Study of Ethnomathematics: A lesson from the Baduy Culture. International Journal of Education and Research, 2(10), 681-688.

D'Ambrosio, U. (1985). Ethnomathematics and its place in the history and pedagogy of mathematics. For the learning of Mathematics, 5(1), 44-48.

Deda, Y. N., \& Disnawati, H. (2017). Hubungan motif kain tenun masyarakat Suku Dawan-Timor dengan matematika sekolah. Prosiding Konferensi Nasional Penelitian Matematika dan Pembelajarannya II (KNPMP II) Universitas Muhammadiyah Surakarta, 18 Maret 2017. Hal. 201-209.

Fathani, A. H. (2009). Matematika hakikat dan logika. Yogyakarta: Ar-Ruzz Media.

Fudiyartanto, F.A. (2012). Penerjemahan Butir Budaya dari Bahasa Inggris Ke Bahasa Indonesia. Adabiyyat: Jurnal Bahasa dan Sastra, 11(2), 317-342.

Funan, F. X., \& Mamoh, O. (2019). Eksplorasi Etnomatematika Uem Le'u Insana Dalam Kaitannya Dengan Konsep Geometri. Range: Jurnal Pendidikan Matematika, 1(1), 63-75.

Indriaini, Popi. (2016). Implementasi Etnomatematika Berbasis Budaya Lokal Dalam Pembelajaran Matematika Pada Jenjang Sekolah Dasar(Skripsi). Fakultas Tarbiyah Dan Keguruan. Lampung: Institut Agama Islam Negeri (IAIN).

Kofi, M. D., \& Mamoh, O. (2020). Pengembangan Perangkat Pembelajaran Rpp dan Lks Materi Segiempat Dan Segitiga Pada Siswa Kelas Vii Smp Negeri Miomaffo Barat Menggunakan Pendekatan Etnomatematika. Math-Edu: Jurnal Ilmu Pendidikan Matematika 5, No 1 (2020): 1-13.

Nasution. (2003). Metode Penelitian Naturalistik Kualitatif. Bandung: Tarsito.

Prabawati, M. N. (2016). Etnomatematika masyarakat pengrajin anyaman rajapolah kabupaten tasikmalaya. Infinity Journal, 5(1), 25-31.

Puspadewi, Kadek R. (2014). Etnomatematika Dibalik Kerajinan Anyaman Bali. Jurnal 


\section{MATH-EDU: Jurnal Ilmu Pendidikan Matematika}

https://doi.org/10.32938/jipm.6.2.2021.31-41

Natun, A. Y. H., dkk.

Matematika, vol.4, no.2, email: rahayupuspa23@yahoo.co.id (diakses pada 23 April 2017). Putri, L. I. (2017). Eksplorasi etnomatematika kesenian rebana sebagai sumber belajar matematika pada jenjang MI. Jurnal Ilmiah Pendidikan Dasar, 4(1).

Septi, Indriyani. (2017). Eksplorasi Etnomatematika Pada Aksara Lampung(Skripsi). Fakultas Tabiyah Dan Keguruan. Universitas Islam Negeri Raden Intan Lampung.

Son, A. L. (2017). Study ethnomatematics: pengungkapan konsep matematika dan karakter siswa pada permainan kelereng masyarakat suku Dawan. Jurnal of MEDIVES, 1(2), 100-110.

Walle, J. A. V. (2006). Matematika sekolah dasar dan menengah. Erlangga: Jakarta

Zhang, W., \& Zhang, Q. (2010). Ethnomathematics and its integration within the mathematics curriculum. Journal of Mathematics Education, 3(1), 151-157. 